\title{
Fear for Manufacturing? China and the Future of Industry in Brazil and Latin America*
}

\author{
Rhys Jenkins ${ }^{\dagger}$ and Alexandre de Freitas Barbosa*
}

\begin{abstract}
There has been considerable concern in Latin America over the implications of increased competition from China for local industry. These concerns include the possibility of "deindustrialization," the increased "primarization" of the region's exports and the difficulties of upgrading manufactured exports into higher technology products. This article examines the impact of Chinese competition both in the domestic market and in export markets on Brazilian industry. It documents the increased penetration of Chinese manufactures in the Brazilian market and the way in which Brazilian exports have lost market share to China in the US, European Union and four Latin American countries. Brazil, because of its more developed and locally integrated industrial sector, is not typical of other Latin American countries and the article also discusses the relevance of the Brazilian experience for the region as a whole.
\end{abstract}

Keywords: Brazil; Latin America; imports; exports; deindustrialization; Chinese competition

The last decade has seen major transformations in the global economy. One of the most, if not the most, significant of these has been the re-emergence of China as a major economic power. It is now the world's second largest economy in terms of GDP after the United States and has overtaken Germany as the world's largest exporter. The first decade of the 21 st century began with China becoming a member of the World Trade Organization (WTO) which signalled a key step in its integration with the global economy. The end of the decade saw the developed world still struggling with the aftermath of the global

* This article is based on research carried out under the UK ESRC Pathfinder Research Project, Brazilian Manufacturing in the face of Chinese Competition: Economic Restructuring, Competitiveness and Employment (Research Grant RES-238-25-0006). We are grateful to Gustavo Gomes de Freitas and Ângela Cristina Tepassê for research assistance.

University of East Anglia. Email: r.o.jenkins@uea.ac.uk

* University of São Paulo. Email: afbarbosa@usp.br 
financial crisis, while emerging economies, led by China and India, have recovered rapidly.

These changes have major implications for Latin America and particularly for the region's industrial development. While several Latin American countries have benefited from the rapid growth of primary product exports to meet the expanding Chinese demand for minerals and agricultural inputs, and from the higher world prices for these commodities to which China has contributed, ${ }^{1}$ the growth of China has posed serious challenges to Latin American manufacturers on two fronts. First, throughout the region, imports from China have grown rapidly, increasing the competitive pressures on local producers who have accused China of dumping and unfair competition. At the same time, those countries which had developed significant exports of manufactures, both to developed countries and to other Latin American countries, have also seen their foreign markets threatened by Chinese products.

Brazil, as the largest economy in the region with the most developed industrial sector in terms of size and degree of integration, is a particularly interesting case study for analysing the implications of China's expansion for Latin American manufacturing. If Brazilian industry is unable to stand up to Chinese competition, there is little hope for manufacturing in the rest of the region. However, if Brazil can use the emergence of a new manufacturing centre in the global economy to leverage its own industrial development, then this may generate opportunities for other Latin American countries.

The next section discusses the concerns that have been raised in the region over the implications of China's economic expansion for the manufacturing sector. This is followed by a more detailed analysis of the Brazilian situation, focusing on the debate over "deindustrialization" and the impact of Chinese competition in the domestic market on Brazilian manufacturers. Although there has been a significant increase in import penetration from China, the article shows that this has come partly at the expense of imports from other countries and was not leading to deindustrialization. However, a hollowing out of Brazilian manufacturing may come about if a new set of policies is not undertaken.

The article then turns to the competition faced by Brazilian exporters in their major foreign markets, the United States, European Union and other Latin American countries. While firms selling in the domestic market have been partly protected from Chinese competition by the Brazilian government, protectionist policies do not help in the case of exports. As a result, the impact of China on Brazilian exports of manufactures has been more significant and affected a wide range of industries. The final section discusses how far the Brazilian situation is representative of that in other countries in the region and what the wider implications might be for Latin America.

1 R. Jenkins, "El 'efecto China' en los precios de los productos básicos y en el valor de las exportaciones de América Latina," Revista CEPAL, No. 103 (2011), pp. 77-93. 


\section{China and Latin American Manufacturing}

Growing competition from China has been a cause of concern for manufacturers throughout Latin America for a number of years now. As early as 2001-03 it was being claimed that in Mexico maquiladoras on the border with the United States and electronics companies manufacturing PCs and telecommunication products in the state of Jalisco were re-locating to China with significant negative effects on employment. ${ }^{2}$ Following the ending of the WTO's Agreement on Textiles and Clothing at the beginning of 2005, textile mills and clothing factories in Central America were reported to be laying off workers and closing down as a result of Chinese competition in the US market. ${ }^{3}$ The Colombian Association of Textile Producers complained that they were being displaced by Chinese products in both domestic and export markets, while in Peru the National Industry Society accused China of dumping textiles and garments at prices that did not even cover the cost of the raw materials they incorporated. ${ }^{4}$ In Brazil the Federacão das Indûstrias do Estado de São Paulo and a number of sectoral associations representing industries affected by Chinese competition have called for increased government support and implementation of safeguard measures against China. ${ }^{5}$

At a regional level calls have been made for joint actions to stem the tide of Chinese competition. At the World's Eighth International Footwear Congress held in Guanajuato, Mexico in 2010, China was strongly criticized, and the president of Argentina's Chamber of Footwear called on Latin American countries to join and form a strong united front "to defend local industries from the diverse Chinese practices such as under-billing or using Panama to triangle and ship their shoes to the rest of the continent." "The president of the Mexican steel association, CANACERO, pointed to the impact that Chinese competition is having on the region's steel industry at a meeting of directors of the Instituto Latinoamerican del Fierro y el Acero in Mexico City in May 2011, ${ }^{7}$ while the president of the Instituto has spoken of the need to reverse the process of deindustrialization in the region. ${ }^{8}$

Thus it is clear that the concerns of manufacturers over Chinese competition are found throughout the region from Mexico to Argentina. They are also prevalent in a wide range of industries from traditional labour-intensive activities such

2 E. Dussel Peters, Economic Opportunities and Challenges Posed by China for Mexico and Central America (Bonn: German Development Institute, 2005), pp. 111-12.

3 G. Thompson, "Mill closings hit hard in Central America," New York Times, 25 March 2005.

4 Helen Murphy, Christopher Swann and Mark Drajem "Economic outlook: competition from China squeezes developing countries," International Herald Tribune, 2 April, 2007.

5 F. Paraguassu "O tamanho de ameaca," Industria Brasileira, Abril 2007.

6 "Latam shoe industry calls for 'united front' against China's disloyal practices," Montevideo: MercoPress, South Atlantic News Agency, 23 October 2010.

7 CANACERO, "México y Latinoamérica preocupados por los procesos de desindustrializatión en la región,” Mexico City press release, 9 May 2011.

8 "Novegil alerta por proceso de desindustrialización en Latinoamérica durante congreso del acero en Brasil" press release downloaded from http://www. ternium. com. mx/saladeprensa/noticias/7470 (4 July 2011). 
as clothing, footwear and furniture to more technologically advanced and capital-intensive sectors such as steel and electrical and electronic products.

There are two distinct but related aspects to the concern of Latin American industrialists about Chinese competition. The first is the increased competition which they face in their domestic markets from Chinese products. This has led to pressure for governments to adopt protectionist measures, including application of anti-dumping and safeguard measures against imports of Chinese goods. These have been particularly frequent in Brazil and Argentina which between them accounted for over 80 per cent of the anti-dumping investigations against China in Latin America in recent years. ${ }^{9}$ Nevertheless China's share in Latin American imports has increased substantially over the past decade.

The second concern is the loss of export markets to China both in the major developed country markets and in intra-regional trade. Here protectionist measures are of no assistance and the focus of industrialists' complaints tend to be on the lack of a competitive exchange rate, high local taxes and interest rates or other additional cost burdens which put Latin American exporters at a cost disadvantage vis-à-vis China.

While industrialists are concerned with their immediate economic interests and the threat that China poses to their market share and profitability, academic commentators on the impact of China on Latin America have looked beyond the effect on individual companies and industries to raise concerns over the broader systemic effects of the rise of China. Many of these concerns also pertain to the impact on the industrial sector. In a much cited article, Brazilian economist Mauricio Mesquita Moreira raised the question: "Is there a future for manufacturing in Latin America?" 10 Gallagher and Porzecanski have also focused on the implications of China for the future of Latin American industrialization in a recent book The Dragon in the Room. ${ }^{11}$

There are several aspects to the impact of Chinese competition which these and other authors see as negative for Latin America. First is the possible "deindustrialization" of the region's economies as local industrial production is displaced by Chinese imports. Second, the rapid movement of China up the technological ladder from labour intensive low tech products such as garments and toys to more sophisticated products such as electronics and machinery makes it more difficult for the Latin American countries to upgrade their own industries and tends to trap the region in less dynamic industrial sectors. ${ }^{12}$ Finally, the combined effect of surging Chinese demand for commodities and intense competition from Chinese manufactured goods in export markets has contributed to a

9 CEPAL, La República Popular China y América Latina y el Carbie: Hacia una nueva fase en el vínculo económico y comercial (Santiago: Naciones Unidas, 2011), p. 21.

10 Mauricio Mesquita Moreira, "Fear of China: is there a future for manufacturing in Latin America?" World Development, Vol. 35, No. 3 (2007), pp. 355-76.

11 K. Gallagher and R. Porzecanski, The Dragon in the Room: China and the Future of Latin American Industrialization (Stanford, CA: Stanford University Press, 2010).

12 Ibid. ch. 4. 
"primarization" of Latin American exports, in other words an increased reliance on primary commodities as a source of foreign exchange. This is seen as bringing with it the age-old problems associated with dependence on primary products.

These arguments take us back to the original theoretical framework of the Economic Commission for Latin America (ECLAC). Although the recent improvements in the terms of trade of primary commodities, stimulated partly by China's rise, may make the emphasis on deteriorating terms of trade seem outdated, it is still necessary to consider the risk of pushing the Latin American economies into a pattern of specialization that would harm their potential for a sustainable increase in productivity levels.

The secular deterioration of the terms of trade was never seen by ECLAC as its most important cornerstone. Its founding fathers took it as an historical feature, not a universal truth. In Prebisch's original formulation in 1949, ${ }^{13}$ what mattered was the fact that international prices did not follow the trends in productivity in that specific context. As a consequence, the only way out, at that point, was industrialization. The underlying structural problem was the concentration of productivity gains at the centre, which at that time manifested itself through the worsening of the terms of trade, backed by different social coalitions in the centre as well as at the periphery. While the deteriorating terms of trade helped to attack comparative advantage theory at that time, ${ }^{14}$ it does not necessarily follow that the opposite trend supports it, since productivity gains may be concentrated through other mechanisms today.

The risk is that this new "visible hand of China," if accepted passively, could bring about a less integrated productive structure and although economic growth might increase, this could be accompanied by increases in the levels of inequality in Latin America, already the highest in the world. As Fajnzylber ${ }^{15}$ recognized in the late 1970s, in the context of arguing the case for adding more value to the region's natural resources as a way of increasing its participation in the world economy, the very engine of social and economic transformation should be sought in endogenous factors.

Not all commentators shared the view that China would have such a negative impact on Latin America or on the industrial sector in particular. Studies from the World Bank ${ }^{16}$ and the OECD ${ }^{17}$ present a more optimistic picture. They argue that on the whole the Latin American economies are complementary to, rather than competitive with, China (with the important exception of Mexico

13 R. Prebisch, "El Desarrollo Econômico de la América Latina y algunos de sus Principales Problemas," in Cincuenta Años de Pensamiento en la CEPAL - Textos Seleccionados, Vol. 1 (Santiago: CEPAL, 1998).

14 R. Bielschowsky, Pensamento Econômico Brasileiro: O Ciclo Ideológico do Desenvolvimentismo (Rio de Janeiro: Contraponto, 1995), 2nd ed.

15 F. Fajnzylber, "Industrialización en América Latina: de la 'Caja Negra al Casillero Vacío'," in Cincuenta Años de Pensamiento en la CEPAL - Textos Seleccionados, Vol. 2. (Santiago: CEPAL, 1998).

16 D. Lederman, M. Olarreaga and G. Perry (eds.), China's and India's Challenge to Latin America: Opportunity or Threat? (Washington, DC: The World Bank, 2009).

17 Javier Sanitso (ed.), The Visible Hand of China in Latin America (Paris: OECD, 2007). 
Figure 1: China and Hong Kong's Exports to Latin America, 1990-2010

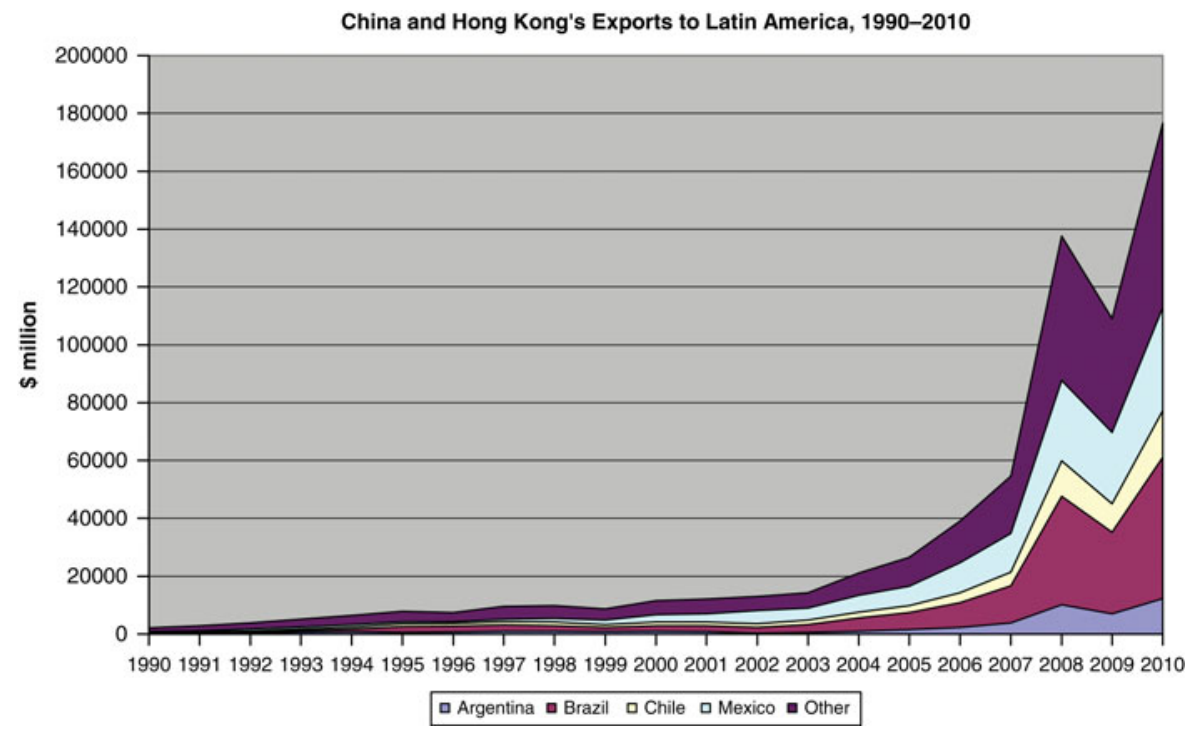

Source:

IMF, Direction of Trade Statistics.

(colour online)

whose relationship is much more one of competition). As a result the negative impacts on the region are outweighed by the gains to exporters of primary commodities and to consumers who benefit from Chinese competition in the domestic market. In the Brazilian case it has also been claimed that imports of capital goods and intermediate products which make up the bulk of imports from China can help increase the competitiveness of Brazilian industry. ${ }^{18}$

\section{The growing penetration of the Latin American market by Chinese goods}

The growth of Chinese exports to Latin America over the past decade has been dramatic. Although these fell in 2009 as the global financial crisis led to an economic slow-down in the region, they bounced back sharply in 2010 to around $\$ 175$ billion, more than 15 times their level in 2000 (see Figure 1). As Table 1 shows, China is amongst the top three sources of imports for all the major Latin American countries and its share of the region's imports has increased five-fold to 12.5 per cent in 2009 .

Although some of the increase in China's share of Latin American imports may have been at the expense of other exporters to the region, this by no means explains all its growth. Another way of looking at the increased level of

18 "China has become a strategic supplier for Brazilian manufacturers in diverse sectors, which have benefited from the low cost of Chinese products to guarantee technological renovation and expansion of Brazil's industrial base," Conselho Empresarial Brasil-China, China-Brazil Trade Report, Year 1, Issue 1 (2008), p. 4. 
Table 1: China's Position in Imports of Major Latin American Markets

\begin{tabular}{lccrr}
\hline & \multicolumn{2}{c}{ Ranking } & & \multicolumn{2}{c}{ Value (\%) } \\
& $\mathbf{2 0 0 0}$ & $\mathbf{2 0 0 9}$ & $\mathbf{2 0 0 0}$ & $\mathbf{2 0 0 9}$ \\
Argentina & 4 & 3 & 4.8 & 12.5 \\
Bolivia & 7 & 4 & 3.5 & 4.3 \\
Brazil & 11 & 2 & 2.8 & 13.0 \\
Chile & 4 & 2 & 5.4 & 11.8 \\
Colombia & 9 & 2 & 2.3 & 11.5 \\
Mexico & 7 & 2 & 1.9 & 14.0 \\
Paraguay & 3 & 1 & 11.4 & 30.3 \\
Peru & 9 & 3 & 4.3 & 15.1 \\
Uruguay & 7 & 3 & 2.0 & 10.3 \\
Venezuela & 18 & & & 9.6 \\
Sources: & & 2 & & \\
$\quad$ Ranking - CEPAL China y América Latina, Cuadro 4; Share - IMF, DOTS. & &
\end{tabular}

import penetration from China is as a share of the total domestic consumption of manufactured goods, and although this is much lower than the Chinese share of imports, by definition, it has nevertheless also increased significantly. The next section considers the extent and consequences of competition from Chinese imports for Brazilian manufacturing in more detail.

\section{Chinese competition in Latin America's export markets}

Much of the debate on the impact of China on Latin American industry has been focused on the effects on exports of manufactures to third markets. China's share of imports to the US doubled from around 10 per cent in 2001 when it joined the WTO to almost 20 per cent in $2009 .{ }^{19}$ Its share of the EU's imports also almost doubled from just over 8 per cent to almost 16 per cent over the same period. ${ }^{20}$ As noted above, China's share of Latin American imports has increased even more rapidly, from 2.6 per cent in 2000 to 12.5 per cent in 2009.

The academic debate revolves around the extent to which these Chinese imports to the major developed country markets compete with the products that the Latin American countries export to those markets. Early studies concluded that Latin American economies, with the notable exception of Mexico, were less likely to be affected by Chinese competition than other economies, particularly those in Asia or Eastern Europe. ${ }^{21}$ Most of these studies used a flawed

19 Own elaboration from USITC database. Import data refer to China and Hong Kong.

20 Own elaboration from EU COMEXT database. Import data refer to 15 EU countries' imports from China and Hong Kong.

21 See e.g. Jorge Blázquez-Lidoy, Javier Rodríguez and Javier Santiso, “'Angel or devil?' China’s trade impact on Latin American emerging markets," in Javier Sanitso (ed.), The Visible Hand of China in Latin America (Paris: OECD, 2007), pp. 45-83; Patricio Meller and Gabriela Contreras, "La competitividad de las exportaciones chinas en los mercados de Estados Unidos y Japon," CIEPLAN Serie Estudios SociolEconómicos No. 16 (2003); P. K. Schott, The Relative Competitiveness of China's Exports to the United States vis á vis Other Countries in Asia, the Caribbean, Latin America and the OECD (New Haven: Yale School of Management, mimeo, 2004). 
measure of the extent of competition between China and the various Latin American countries, the Export Similarity Index. ${ }^{22}$ However Lall and Weiss, using a different methodology based on analysing changes in the world and US market shares of China and Latin American countries, came to a similar conclusion: "The direct threat to exports to third country markets appears small: Latin America and the Caribbean's (LAC's) trade structure is largely complementary to that of China."23

Such optimistic conclusions were at odds with the growing complaints from industrialists about the loss of export markets to China and evidence of the relocation of some production to China. A number of more recent studies, using different indices and methodologies and more up-to-date data, have also questioned the optimism of the earlier research. These later studies suggest that the impact of Chinese competition on Latin American exports to the United States has been more serious than originally predicted, both in terms of the range of industries and the number of countries affected. ${ }^{24}$ There have so far been relatively few studies looking at the effects of China on Latin American exports to other markets such as the EU and on intra-regional trade, but the evidence also suggests that some Latin American countries face significant Chinese competition in those markets too. ${ }^{25}$ The impact of Chinese competition on Brazilian exports to the US, EU and several Latin American countries is considered in more detail below.

\section{China and the Singularity of Brazilian Manufacturing}

Since 2006, there has been a heated debate in Brazil over what some analysts depict as the "deindustrialization" of the country's economy, ${ }^{26}$ paralleled by a

22 For a critique of the use of the ESI to measure the extent to which countries' exports are exposed to competition from China, see R. Jenkins, "Measuring the competitive threat from China for other southern exporters," The World Economy, Vol. 31, No. 10 (2008), pp. 1351-66.

23 Sanjaya Lall and John Weiss, "China's competitive threat to Latin America; an analysis for 19902002," Oxford Development Studies, Vol. 33, No. 2 (2005), p. 163.

24 C. Freund and C. Ozden, "The effect of China's exports on Latin American trade with the world," and G. Hanson and R. Robertson, "China and the recent evolution of Latin America's manufacturing exports" both in D. Lederman, M. Olarreaga and G. Perry (eds.), China's and India's Challenge to Latin America: Opportunity or Theat? (Washington, DC: The World Bank, 2009); R. Jenkins, "China's global growth and Latin American exports," in A. Santos Paulino and G. Wan (eds.), The Rise of China and India (Basingstoke: Palgrave, 2010); Gallagher and Prozecanski, Dragon in the Room, ch. 3.

25 On competition between China and the Latin American countries in the EU see R. Jenkins, "Chinese competition and Latin American exports to the United States and the European Union," paper presented at the workshop "From the Great Wall to the New World: China and Latin America in the 21st century" held at UCLA, 15-16 April 2011. On competition with intra-regional exports in Latin America see Gallagher and Porzecanski, Dragon in the Room, pp. 51-56.

26 For a review of this debate, one of the principal advocates of the deindustrialization thesis is L.C. Bresser Pereira, "Brasil Vive Desindustrialização," in Folha de São Paulo, 28 August 2010; a critical view is expressed by A. Nassif, "Há Evidências de Desindustrialização no Brasil?" Brazilian Journal of Political Economy, Vol. 28, No. 1 (2008); and R. Bonneli and S.A. Pessoa, Desindustrialização no Brasil: um Resumo da Evidência, Texto para Discussão, No. 7 (Rio de Janeiro: IBRE/FGV, 2010); a more subtle approach, defending the approach of a "relative deindustrialization" can be found in J. Almeida, P. Carvalho and C. Feijó, Ocorreu uma Desindustrialização no Brasil? (São Paulo: IEDI, 2005). 
"primarization" of its exports. Although these concepts capture some aspects of reality, they hamper understanding of the complete picture, namely the new dynamics of the Brazilian economy and the role played by manufacturing.

China has increasingly been seen as a factor (together with the overvalued exchange rate) contributing to these trends. However it can be argued that Brazil's asymmetrical relation with China arises from the different patterns of development and integration with the world economy followed by the two countries in the recent past. In addition, the deindustrialization thesis cannot be accepted without a deeper understanding of the way in which different sectors of Brazilian manufacturing have been affected by Chinese competition in the domestic and external markets over the past decade.

This section sheds some light on the nature of the industrialization process from 1930 to 1980, and the adjustment to the new international context in the 1990s, in order to show how and why manufacturing has been able to recover since 2003 and even after the financial crisis. It seems more accurate to discard the deindustrialization thesis and to consider two alternative patterns that may be followed in the near future: a "hollowing out" of the manufacturing sector; or its reshaping through the maintenance of some integrated, but increasingly reduced, productive chains and by taking advantage of the internal market in order to foster the development of new technologies. These alternatives provide some space for action on the part of government - macroeconomic, industrial and technological policies - and of other economic actors as well. The pattern that emerges depends on how Brazilian industry adapts and reinvents itself in order to face increasing Chinese competition.

The Brazilian case is not only different from others in Latin America but may also affect - through the regional integration processes - the very nature of the Chinese impact on the whole region. Barros de Castro $^{27}$ has argued that the less developed and diversified an economy on the eve of entry into a global economy increasingly redefined by China, the faster it will grow, provided it can meet the profile and the magnitude of Chinese demand. For instance, economies that have already undergone deindustrialization or that did not advance to the more complex stages of import-substitution, such as Chile and Peru, were able to adapt to this new context without serious disruptions to domestic production; whereas, in the cases of Argentina, Brazil and Mexico, China's rise tends to bring about more traumatic structural adjustments. Of the latter, Brazil is the only one to preserve a coherent and partly integrated manufacturing industry, driven by the internal market and not excessively reliant on manufactured exports.

A number of writers ${ }^{28}$ have shown the way in which from the 1930s Brazil, unlike most other Latin American countries which only managed to build up

27 A. Barrros de Castro, "From semi-stagnation to growth in a Sino-centric market," Brazilian Journal of Political Economy, Vol. 28, No. 1 (2008).

28 For this debate, see C. Furtado, A Economia Latino-Americana: Formação Histórica e Problemas Contemporânenos (São Paulo: Companhia Editora Nacional, 1986), 3rd ed.; I. Rangel, "Economia: Milagre e Antimilagre (1985)," in Obras Reunidas, Vol. 1 (Rio de Janeiro: Contraponto, 2005); M.C. 
"enclave industries," experienced an "authentic industrial transformation." Their interpretations are useful in the current debate in Brazil and the rest of Latin America. In countries such as Chile, Colombia, Peru and Venezuela where manufacturing never matured, industrial regression was a real possibility. This was not the case in Brazil and even the competitive pressures of the 1990s were not enough to do away with it.

Nevertheless, the political battle was won by those who regarded Brazilian industry as inefficient, seeking quasi-rents and struggling for self-reliance. They were able to implement the Real Plan, which was more than a stabilization policy and paved the way for a new insertion into the global economy and a new model of development through opening the internal market, attracting FDI and privatization as part of a strategy to increase productivity and competitiveness. A falling share of manufacturing in GDP was seen as a natural outcome of this new approach and was not considered a problem by the proponents of the Real Plan since Brazil, it was argued, had over-industrialized. ${ }^{29}$

Manufacturing was the sector most severely affected by the new competitive pressures brought about by the combination of an overvalued currency, high interest rates and falling tariffs during the 1990s. Despite this the share of manufacturing in GDP which had fallen in the late 1980s, before the opening of the economy, remained almost stable during the 1990s. ${ }^{30}$ Manufacturing has boomed again between 2004 and 2008, and has created more than two million jobs during this period. Sectors defined as differentiated (machinery and electronics), labourintensive (garment, textile, footwear, food and beverages) and scale intensive (automotive, steel and chemicals) grew faster than or very close to the manufacturing average in terms of value-added and employment, despite rapid growth of imports from China (Table 2).

Thus, even though Brazil is not deindustrializing, its manufacturing industry needs to adapt its structure to a new context of more dynamic internal growth and increasing Chinese competition. Otherwise, the industrial structure will be hollowed out, and the investment rate could increase without bringing about a faster economic growth and with the side-effect of a mounting current account deficit. In this situation, employment growth would not be as dynamic as before, as the multiplier effect would be exported. The specific features of the Brazilian economy derive from the more diversified structure of Brazil's exports - including a wide array of commodities needed by China - the greater scale and level of integration across its production chains, especially in manufacturing, and the fact

\footnotetext{
footnote continued
}

Tavares, Da Substituição de Importações ao Capitalismo Financeiro (Rio de Janeiro: Zahar Editores, 1973), 2nd ed.; A. Barros de Castro and F.E. Pires de Souza, A Economia Brasileira em Marcha Forçada (São Paulo: Paz e Terra, 2004), 3rd ed.

29 This view is expressed by G. Franco, O Desafio Brasileiro: Ensaios sobre Desenvolvimento, Globalização e Moeda (São Paulo: Editora 34, 1999).

30 Bonneli and Pessoa. Desindustrialização no Brasil; Nassif, "Há Evidências de Desindustrialização." 
Table 2: Data on Industrial Perfomance of Different Sectors by Type of Technology* on an Year Basis for the Period 2003-2007 (\%)

\begin{tabular}{|c|c|c|c|c|c|}
\hline Indicator/type of Industry & Science-based & Resource-based & Differentiated & Scale-intensive & Labour-intensive \\
\hline Industrial value-added & 0.65 & 2.97 & 11.35 & 4.22 & 6.49 \\
\hline Employment & 3.56 & 5.34 & 7.74 & 4.36 & 4.22 \\
\hline EXPORT_DEST_World & 3.04 & 1.60 & 2.03 & 0.87 & -4.70 \\
\hline EXPORT_DEST_China & 20.91 & 3.27 & -13.16 & -22.03 & -1.71 \\
\hline IMPORT_ORIG_World & 3.44 & 3.71 & 13.07 & 6.36 & 11.44 \\
\hline IMPORT_ORIG_China & 16.44 & -0.52 & 55.69 & 36.94 & 42.82 \\
\hline \multicolumn{6}{|c|}{$\begin{array}{l}\text { Note: } \\
\text { * Classification taken from Nassif, Evidências de Desindustrialização. } \\
\text { Source. }\end{array}$} \\
\hline
\end{tabular}




\section{Figure 2: Brazilian Trade with China, 1996-2007 (US\$ billion)}

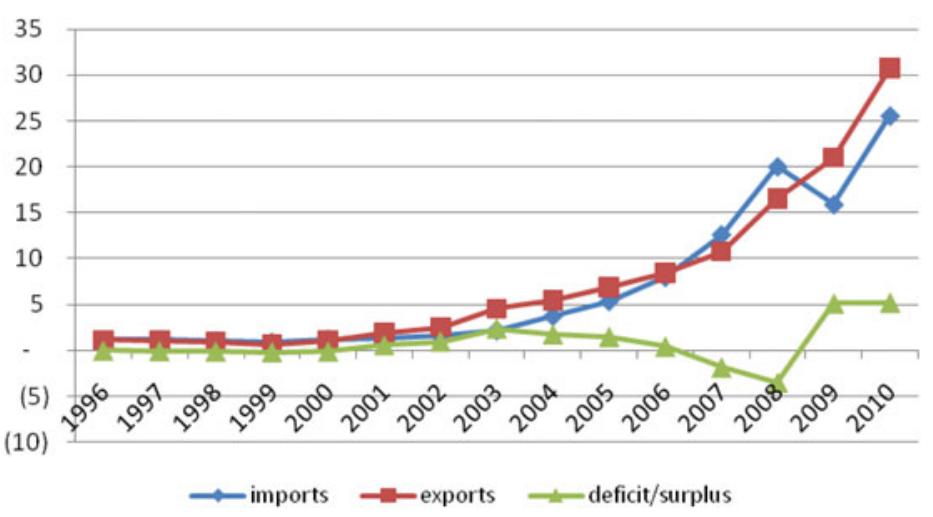

Source:

Aliceweb/MDIC. Elaborated for the ESRC/Cebrap project.

that Brazil's manufactured exports, which go mainly to other Latin American countries, partly coincide with what these countries import from China.

To sum up, we should stress that although Brazil exports mainly commodities to China, it still has a coherent industrial structure, mainly supplying the national and regional markets. Brazil also manages to have its big "multinational stars," which have accessed the Chinese market mainly through joint ventures with Chinese companies. On the other hand, Chinese investments, although rising recently, are mainly concentrated on commodities and mainly involved mergers and acquisitions. Some Chinese manufacturers (from the automotive and electronic sectors) are beginning to come in as well, albeit more slowly, through trade representatives or small green-field investments. ${ }^{31}$

\section{Chinese competition in the Brazilian market}

Figure 2 shows the rapid growth of trade between Brazil and China, particularly over the past decade. It also shows that Brazil enjoyed a trade surplus with China for most of the period, although this declined from its peak in 2003 as the Brazilian economy recovered, turning into a deficit of around US\$4 billion in 2008. In 2009 this returned to surplus but it seemed that only a combination of slow growth in Brazil and a still dynamic Chinese economy would be able to assure a trade surplus for Brazil. ${ }^{32}$ However, the data for 2010 presented a new scenario: a growing deficit in manufactured goods more than offset by Brazilian commodity exports, which can only be explained by its ability to supply

31 CEBC, Investimentos Chineses no Brasil: uma Nova Fase da Relação Brasil-China (Rio de Janeiro: CEBC, 2011).

32 A.F. Barbosa, and A.C. Tepassê, "O Ciclo da Economia Global e as Relações Comerciais entre Brasil e China," in Henrique Altemani (ed.), China e Índia na América Latina - Oportunidades e Desafios (Curitiba: Juruá Editora. 2009). 
Figure 3: China's Share in Total Brazilian Manufactured Exports and Imports, 1996-2010 (\%)

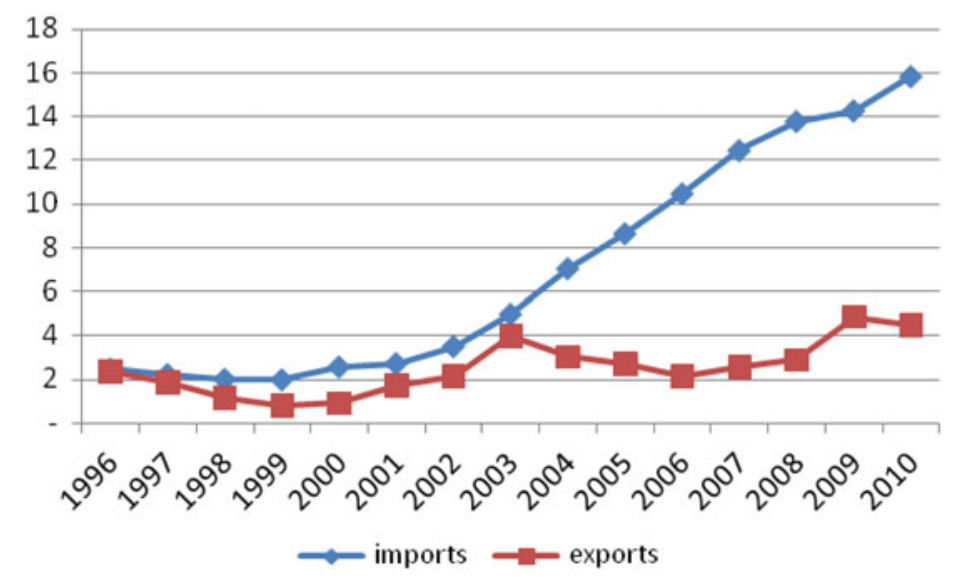

Source:

Aliceweb/MDIC. Elaborated for the ESRC/Cebrap project.

(colour online)

more primary products, adding crude oil to the basket of Brazilian exports to China.

The picture for trade in manufacturing is totally different. China's share of Brazilian imports of manufactures rose from less than 2 per cent in 1996 to 16 per cent in 2010, while exports to China accounted for only 4.5 per cent of total Brazilian exports of manufactures (see Figure 3). ${ }^{33}$ As a result Brazil had a substantial trade deficit with China in manufactured goods of US\$15 billion in 2008, which fell to US\$10 billion in 2009 as the economy slowed down in the midst of the international crisis (Figure 4). In 2010 internal demand boomed and, aggravated by the overvalued Real, Brazil's overall trade deficit in manufacturing jumped to US\$30 billion of which China accounted for two-thirds (US $\$ 19.5$ billion).

We turn now to the types of manufactured goods that Brazil imports from China. Figure 5 shows that it is not durable and non-durable consumer goods that have led to the growing Brazilian deficit. In 2010, the deficit in intermediate goods came to US $\$ 10.7$ billion with a further US\$5.4 billion in capital goods, so that between them these accounted for 82 per cent of the overall trade deficit with China in manufacturing. Looking in more detail at the sectors with the largest trade deficit, these tend to be mainly in machinery and parts and components for the electronics industry, followed by intermediate goods for the steel and chemical industries (Table 3).

In contrast to the deindustrialization thesis, the significant share of intermediate and capital goods in Brazil's imports might imply that China was bringing 
Figure 4: Brazilian Trade in Manufactures with China, 1996-2010 (US\$ billion)

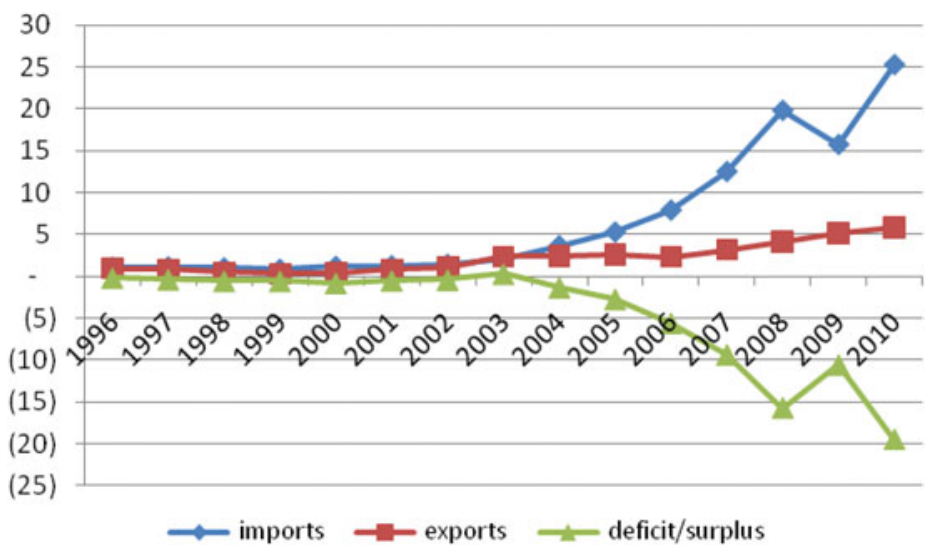

Source:

Figure 5: Brazil's Trade Surplus/Deficit by End of Use Categories of the Manufacturing Industry with China, 1996-2010 (US\$ million)

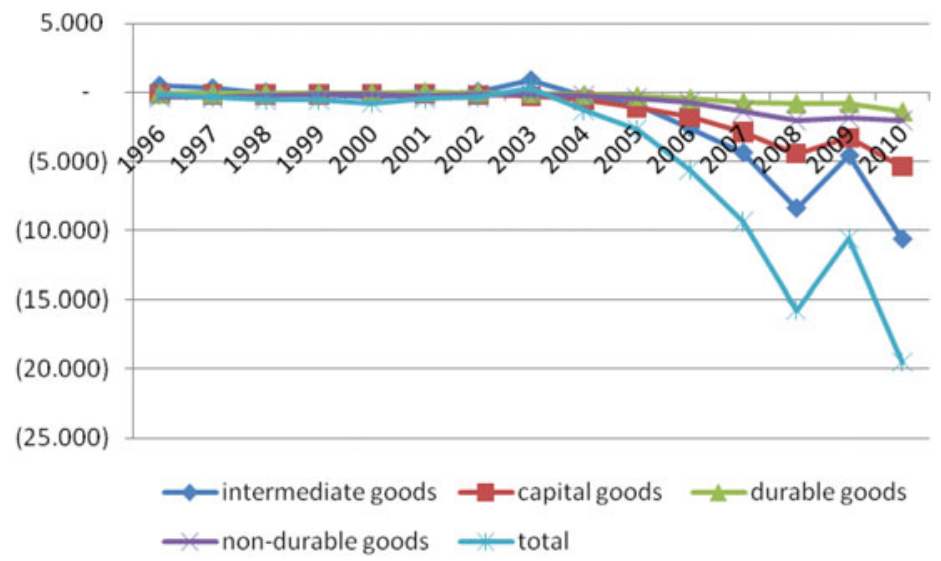

Source:

about the modernization of Brazilian manufacturing. Reliance on increased imports of intermediate goods could also indicate that Brazil is jumping into maquiladora type industry based on simply assembling final goods, thus paving the way for a hollowing out of its industrial base.

Analysing trade deficits by sector does not indicate the extent of Chinese competition in the Brazilian market. This requires estimates of the extent of Chinese import penetration, defined as the share of Chinese imports in apparent 


\section{Table 3: Brazilian Manufacturing Sectors with the Largest Trade Deficits with China from 2004 to 2010 (US\$ million)}

\begin{tabular}{lrrrr}
\hline Industrial sectors & 1996 & $\mathbf{2 0 0 4}$ & $\mathbf{2 0 0 8}$ & $\mathbf{2 0 1 0}$ \\
Instruments for radio/TV reception and reproduction & -126 & -368 & $-1,236$ & $-2,151$ \\
Machinery and electronics equipment for data processing & -21 & -221 & $-1,768$ & $-2,149$ \\
Basic electronic material & -12 & -307 & $-1,114$ & $-1,607$ \\
Telecommunications equipment & -24 & -310 & $-1,906$ & $-1,497$ \\
General machinery and equipment & 4 & -44 & -628 & $-1,309$ \\
Steel industry & 72 & 363 & -732 & $-1,223$ \\
Diverse products & -143 & -116 & -558 & -751 \\
Organic goods for the chemical industry & -66 & -193 & -752 & -738 \\
Electrical engines, power generators and transformers & -23 & -90 & -491 & -668 \\
Optical, photographic and movie equipment & -40 & -198 & -876 & -580 \\
Household appliances & -34 & -37 & -339 & -485 \\
Inorganic goods for the chemical industry & -8 & -64 & -743 & -406 \\
Source: & & & &
\end{tabular}

Aliceweb/MDIC. Elaborated for the ESRC/Cebrap project.

consumption of manufactured products in Brazil. ${ }^{34}$ Figure 6 shows the overall level of import penetration both for all imports and for imports from China. Although Chinese import penetration remains relatively low, it increased more than ten-fold between 1996 and 2007 to account for 3.4 per cent of consumption, while overall import penetration has been at around 18 per cent. Since 2007 import penetration has continued to grow and we estimate that currently it is around 5 per cent for China and over 20 per cent for all imports.

It is striking how much the coefficients vary across sectors. By classifying them once again according to Nassif's methodology by type of technology, it can be seen that in the differentiated sectors (machinery and electronics) Chinese import penetration grew more than three times in a very short period, reaching 10 per cent of apparent consumption (Figure 7). Even more interesting, in these sectors, the world import penetration coefficient actually fell to 37 per cent in 2007. Labour-intensive sectors also saw a three-fold increase in Chinese import penetration from less than 1 per cent in 2003 to 2.9 per cent in 2007, accounting for almost a third of total import penetration in these industries. This suggests that the rapid increase in Chinese import penetration has been, at least in part, at the expense of imports from other countries and has not necessarily displaced local production in Brazil. Analysis of sectoral changes in the share of domestic production, Chinese imports and imports from the rest of the world showed that over half the increase in Chinese penetration of the Brazilian market since it joined the WTO in 2001 has been at the expense of imports from elsewhere. ${ }^{35}$

34 Apparent consumption is defined as the gross value of industrial production plus imports of manufactures minus exports of manufactures.

35 See R. Jenkins and A. Barbosa, A Ascensão Chinesa e os Dilemas para a Indústria Brasileira: Pressão Competitiva, Reestruturação Econômica e Emprego (São Paulo: Briefing Paper ESRC/Cebrap Project, 2011), Table 5. 
Figure 6: World and Chinese Coefficient of Import Penetration in Brazilian Manufacturing, 1996-2007 (\% of Apparent Consumption)

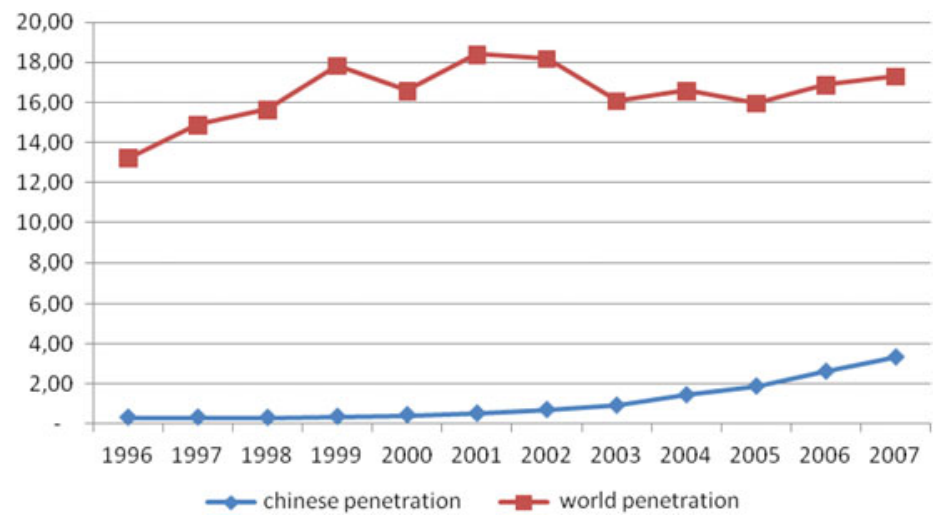

Source:

Aliceweb/Mdic and PIA/IBGE. Elaborated for the ESRC/Cebrap project.

Figure 7: Chinese Coefficient of Import Penetration in Brazilian Manufacturing by Sectors according to Type of Technology, 2003, 2007 (\% of Apparent Consumption)

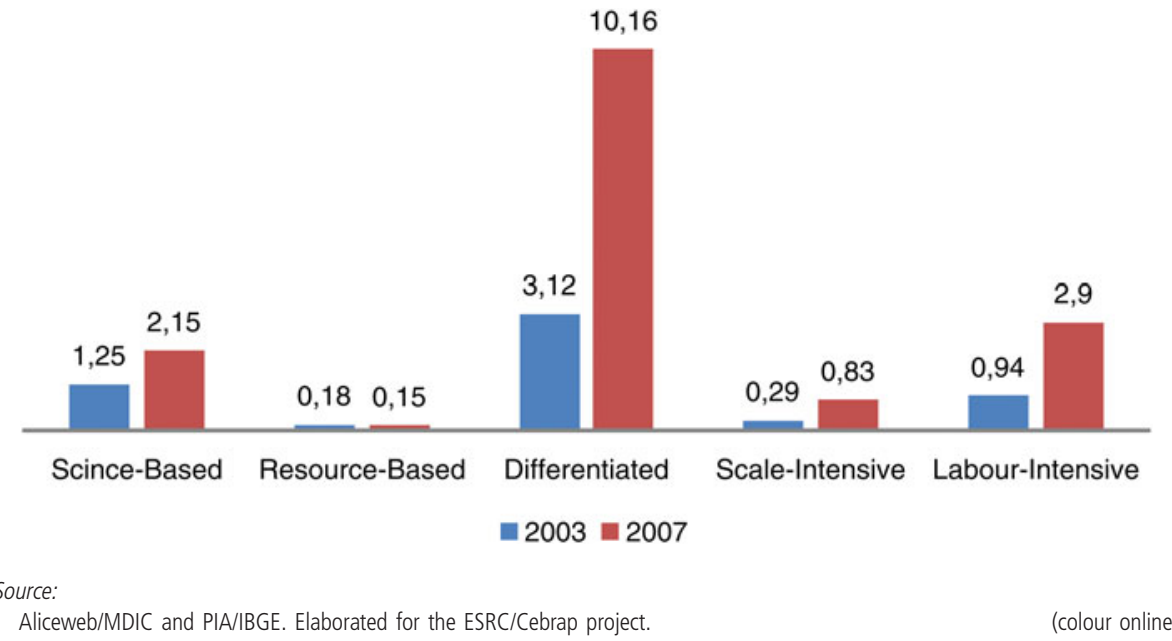

It is also important to point out that most of the sectors with a high coefficient of Chinese import penetration tend to be at the beginning of their production chains. For instance, whereas the coefficient in synthetic fibers is 7.4 per cent, it falls to 4.8 per cent in textiles and to a mere 2 per cent in the garment sector. In electronics as well, whereas in telecommunications equipment, basic electronic material and machinery and electronic equipment for data processing Chinese 
penetration is around 12 per cent, in the case of household appliances (consumer durables) the figure falls to 4.6 per cent. ${ }^{36}$

Thus growing Chinese competition tends to be concentrated more on the early segments of the production chain, particularly those with higher productivity levels. The continuation of this trend could lead to increased specialization and fewer industrial linkages within the manufacturing sector. This should not be seen as an inexorable process if we take into account the policy space for a different set of exchange-rate and interest-rate policies, if supported by industrial and technology policies for some niches and sub-sectors of Brazilian industry. We should also be cautious in extrapolating these figures as though they would continue to grow without eliciting any reaction in Brazil and worldwide. Other countries may well adopt protectionist policies and a stalemate in the ongoing "exchangerate war" with China may also come about.

The competitive pressure on the Brazilian industrial system from China, albeit small, is growing fast and at different speeds across sectors. The continuation of current trends would make the hollowing out of Brazilian manufacturing a real possibility. On the other hand, the size and coherence of the internal market and the public policy options and institutions available mean that a different pattern of development is possible.

\section{Chinese Competition and Brazilian Exports}

It is not only in the domestic market that Brazilian industry has been affected by Chinese competition. Contrary to the expectations of those who predicted that only Mexico amongst the major Latin American countries would face serious problems from Chinese competition in their export markets, the evidence suggests that Brazilian exporters have been affected. A recent survey by the Brazilian National Confederation of Industries reported that over half of the Brazilian exporters covered faced competition from China in foreign markets and that two-thirds of these had lost customers to Chinese exporters. ${ }^{37}$ Several reports by the Sao Paulo Federation of Industries have made estimates of the negative impact of Chinese competition on Brazilian exports to the US, the EU and Argentina suggesting that there have been significant losses. ${ }^{38}$

There have also been academic studies which have analysed the impact of China on Brazilian exports to the US, the EU and to other Latin American countries. ${ }^{39}$

36 Ibid. Table 2.

37 CNI, Sondagem Especial, Ano 9, No. 1, fevereiro de 2011.

38 For example Federaçao das Indústrias do Estado de Sao Paulo, A Ascensao Chinesa e os Prejuízos às Exportaçoes Brasileiras para os Estados Unidos (Sao Paulo: FIESP, 2007); Competicão Brasil-China nos Mercados Externo e Interno (Sao Paulo: FIESP, n.d.)

39 J. Mesquita Machado and G. Tinoco Ferraz, Comercio Externo da China: Efeitos sobre as exportacões Brasileiras (Brasilia: IPEA Texto para Discussão No. 1182, 2006); M. Filgueiras and H. Kume, $A$ Competitividade do Brasil e da China no Mercado Norte-Americano: 2000-2008 (Brasilia: IPEA Texto para Discussão No. 1501, 2010); C. Hiratuka and S. Cunha, Qualidade e Diferenciacão das Exportacões Brasileiras e Chinesas: Evolucão Recente no Mercado Mundial e na ALADI (Brasilia: IPEA Texto para Discussão No. 1622, 2011) 
These too suggest that exports from Brazil to these markets have been affected by Chinese competition. These studies have in the main focused on the degree of competition which Brazil faces from Chinese goods in export markets and the products where this competition occurs. Our research has tried to measure the extent of the impact which Chinese competition has had on Brazilian exports to the various markets. We focus on the US, the EU and Brazil's four most important markets in Latin America - Argentina, Chile, Mexico and Venezuela.

In order to do this we used an extension of Constant Market Share analysis developed by Chami Batista. ${ }^{40}$ The gains (losses) of market shares between countries are related to their relative growth rates. In other words, countries gain from those countries whose exports are growing more slowly and lose to those that are growing faster than their own. ${ }^{41}$

The data were collected for four key years, 1996, 2001, 2004 and 2009. This made it possible to analyse the impact of Chinese competition in three distinct periods. The first, from 1996 to 2001, represents the situation prior to China's WTO accession in December 2001. The period from 2001 to 2004 is a time of transition, before the ending of the WTO's Multifibre Arrangement, which provided for quotas on imports of textiles and garments to developed country markets, on 1 January 2005. ${ }^{42}$ It is also a transition period in terms of the opening of Latin American markets to Chinese competition. Finally, 2004-09 covers the years when Latin American exporters were fully exposed to Chinese competition both in developed country markets and within the region. The use of these three periods makes it possible to analyse how competition between China and Brazil has evolved over time in response to the changes in the trade regime and the global financial crisis.

The data on US imports come from the US International Trade Commission (http://dataweb.usitc.gov/) and those for the European Union from the COMEXT database (http://fd.comext.eurostat.cec.eu.int/xtweb/). Product data at the five-digit level of the SITC (Rev.3) were used. In the case of the Latin American countries, data on imports were obtained from UN COMTRADE for all four countries at the six-digit level of the Harmonized System. ${ }^{43}$ It was

40 J. Chami Batista "Competition between Brazil and other exporting countries in the US import market: a new extension of constant-market-shares analysis," Applied Economics, No. 40 (2008). pp. 2477-87.

41 The loss of market share by Brazil (B) to China (C), in a particular product $\mathrm{i}$ is defined as:

$$
\Delta \mathrm{k}_{\mathrm{Bci}}=\Delta \mathrm{k}_{\mathrm{Bi}} \mathrm{k}_{\mathrm{Ci}}^{\mathrm{t}}-\Delta \mathrm{k}_{\mathrm{Ci}} \mathrm{k}_{\mathrm{Bi}}^{\mathrm{t}}
$$

where:

$\mathrm{k}_{\mathrm{Bi}}$ is the share of Brazil in total imports of good $\mathrm{i}$ by the destination market

$\mathrm{k}_{\mathrm{Ci}}$ is the share of China in total imports of good $\mathrm{i}$ by the destination market

Superscript $t$ represents the initial year of the period.

Summing over all products gives the aggregate loss of market share to China:

$$
\Sigma \Delta \mathrm{k}_{\mathrm{Bci}}=\Sigma \Delta \mathrm{k}_{\mathrm{Bi}} \mathrm{k}_{\mathrm{Ci}}^{\mathrm{t}}-\Sigma \Delta \mathrm{k}_{\mathrm{Ci}} \mathrm{k}_{\mathrm{Bi}}^{\mathrm{t}}
$$

42 Although it should be noted that subsequently the US and the EU imposed new restrictions on Chinese textile and clothing imports.

43 This is even more disaggregated than the five-digit SITC level. 
Table 4: Displacement of Brazilian Industrial Exports by China in the US, EU and selected Latin American Countries, 1996-2001, 2001-2004, 2004-2009 (\%)

\begin{tabular}{lccc}
\hline & $\mathbf{1 9 9 6 - 2 0 0 1}$ & $\mathbf{2 0 0 1 - 2 0 0 4}$ & $\mathbf{2 0 0 4 - 2 0 0 9}$ \\
USA & -0.7 & -9.6 & -5.3 \\
EU & -2.5 & -0.3 & -5.9 \\
Argentina & 0.1 & -0.3 & -6.8 \\
Chile & -1.2 & -1.0 & -14.4 \\
Mexico & -0.4 & -1.2 & -6.6 \\
Venezuela & -0.8 & 0.2 & -8.6
\end{tabular}

Source:

Own elaboration based on USITC, COMEXT and UN COMTRADE data.

important to have a high level of disaggregation in order to ensure that the products being compared were close substitutes for each other.

Table 4 shows how much lower Brazil's exports are in the final year of each period than they would have been if they had not lost market share to China since the initial year. In a few cases (Argentina 1996-2001, Venezuela, 200104) the values are positive, indicating that Brazil gained market share from China in those instances. Prior to China's WTO accession, its impact on Brazilian exports was quite limited but this changed dramatically in the United States from 2001 onwards. In the other markets Brazil did not lose much market share in the years immediately after 2001, but from 2004 onwards there was a significant effect. Interestingly, Brazilian exports of industrial goods to the Latin American countries were affected even more than to the US and the EU in the period from 2004 to 2009. Given that Latin America and the Caribbean account for around half of Brazil's total exports of non-resource based manufactures and that the four countries included here account for about two-thirds of Brazil's exports to the region, the loss of market share here is a serious concern.

Thus, contrary to the optimism of some early commentators, Brazilian exports have not been unaffected by Chinese competition. Products as diverse as footwear, mobile phones, motorcycles, steel tubes, furniture and made-up textiles have been amongst those where Brazil recorded major losses to China in its export markets. This indicates that Chinese competition has not been confined to simple labour-intensive products but has also been faced by Brazilian exporters of more high technology products.

Although the evidence suggests a significant loss of market share to China in Brazil's major export markets, one should be careful not to exaggerate the overall impact that this has had on Brazilian industry. The major part of Brazilian manufacturing production is for the domestic market and exports account for only around a fifth of total output, so that a loss of 5 per cent in exports represents a reduction of only 1 per cent in industrial production. Nevertheless the impact on particular industries, such as footwear and mobile phones where the loss to China was much greater and the share of output exported much higher, was much more serious. 
As far as foreign exchange earnings are concerned, the loss of earnings from manufactured exports is more than offset by the gains obtained from the growth of primary product exports to China and the effect of Chinese demand on global commodity prices in recent years. It has however contributed to a "primarization" of Brazil's exports reflected in almost a doubling of the share of primary products from 22.8 per cent to 44.6 per cent of total exports between 2000 and 2010, while the share of manufactured goods fell from 59.0 per cent to 39.4 per cent. ${ }^{44}$

\section{Brazil in a Regional Context}

To conclude, we shall consider the extent to which the Brazilian experience can be generalized to the rest of Latin America and the implications of the growing Chinese presence for the challenges faced by industry in the region as a whole. As noted at the outset, Brazil has the most developed and most integrated manufacturing sector in the region and the largest domestic market. Despite this, some of the trends observed in Brazil are replicated throughout Latin America.

First and foremost the rapid increase in imports from China is a feature in all the Latin American countries (see Figure 1). Although, as was seen in the Brazilian case, part of the increase in imports from China was at the expense of imports from other countries, it is certain that domestic producers have also faced increased competition in their domestic markets from Chinese products, as the complaints quoted earlier from industrialists in Mexico, Argentina, Colombia and Peru, as well as Brazil, illustrate. Unfortunately there are no studies available which indicate the extent to which Chinese goods compete with other imports or with domestic production in other Latin American countries and this would be an interesting avenue for future research.

Some rough estimates of the average import penetration of the domestic market for manufactured goods suggest that this is somewhat higher in other Latin American countries than in Brazil. In an earlier study we found that in 2006 Chinese imports accounted for 1.7 per cent of the total demand for manufactures in Brazil compared to 2.5 per cent in Argentina. ${ }^{45}$ In Chile in 2006 almost 4 per cent of manufactured goods consumed came from China, while the corresponding figure for Peru and Uruguay in 2007 was almost 5 per cent. ${ }^{46}$ This is not surprising since these other economies are smaller than Brazil and tend to rely more heavily on imported manufactures generally.

Clearly as in the case of Brazil, the average level of Chinese import penetration hides considerable variation between different industries. In Argentina, for

44 Data from SECEX/MDIC. The remaining exports are classified as semi-manufactures.

45 R. Jenkins, "The Latin American case," in Rhys Jenkins and Enrique Dussel (eds.), China and Latin America: Economic Relations in the 21st Century (Bonn: German Development Institute, 2009), p. 37.

46 Own estimates from UNIDO data on industrial production and CEPAL data on trade in manufactured goods. Using the same data sources, the estimate for Brazil in 2007 was $2 \%$. 
example, significant levels of Chinese competition were found in office equipment and computers; electrical motors, generators and transformers; televisions and radios; and electronic components. ${ }^{47}$ Again, unfortunately a lack of detailed case studies prevents us from comparing the extent of import penetration in different industries in other countries.

One important difference between Brazil and most of the other countries in the region is the much higher proportion of intermediate products in the basket of goods that it imports from China. In 2009, 57 per cent of Brazil's total imports from China were intermediate goods, the highest proportion by some way among ten South American countries. The only other Latin American country that approached this proportion was Mexico (52 per cent). ${ }^{48}$ Whereas in Brazil imports of intermediate products were 3.3 times the value of imports of consumer goods from China, the corresponding ratio in Chile and Uruguay was between 0.6 and 0.7, while in Argentina, Colombia, Peru and Venezuela it was between 1.5 and 1.6. This suggests that a process of deindustrialization involving the displacement of producers of final goods and the possible loss of entire sectors of industry is more likely to occur in the other South American countries, particularly in Chile and Uruguay, than in Brazil.

While Brazil is an outlier in the region in terms of the impact of Chinese import competition on production for the domestic market, it is much more representative of competition with China in export markets. In terms of the loss of manufactured export markets to China in the US since China's accession to the WTO, Brazil has been less affected than the Central American countries and the Dominican Republic, and at a similar level to Argentina and perhaps surprisingly Mexico. ${ }^{49}$ It has lost more to China than some of the Andean countries, particularly Chile, Venezuela and Bolivia, whose exports to the US are in any case mainly of primary products. Brazil's exports to the EU were less seriously affected by Chinese competition than to the US after 2001. Its loss of market share in the EU was slightly higher than the average for 19 Latin American countries.

Little is known about the impact of China on regional exports of manufactures from other Latin American countries. Some preliminary data on Mercosur suggests that member countries other than Brazil have not suffered significantly from competition from Chinese imports since they tend to export different products. ${ }^{50}$ In Argentina and Paraguay, declining intra-Mercosur trade was due to the loss of market share by Brazil. In Uruguay the share of intra-regional imports remained stable between 2000 and 2009.

While there are no similar studies for Latin America as a whole, or for other sub-groupings, it seems likely that Brazil is the country whose exports within

47 Jenkins, "The Latin American case," Table 5.

48 Own elaboration from UN COMTRADE data on imports by Broad Economic Category (BEC).

49 Jenkins, Chinese Competition, Table 3.

50 INTAL, "Chinese products' penetration in MERCOSUR imports" INTAL Monthly Newsletter, No. 173, January 2011. 
the region have been most affected by Chinese competition. Mexico, the other significant exporter of manufactures in Latin America, is so strongly linked to the US market through NAFTA that its exports to the region are relatively insignificant. Nevertheless, given the importance of Brazil in intra-regional trade, the hypothesis that China is contributing to regional disintegration in Latin America merits further consideration in future.

If this were the case, it would raise some important policy questions concerning the process of regional integration. Would it be feasible to launch more specific and long-term initiatives (including loans, market access and infrastructure provision from Brazil) in order to foster production and investment complementarity within Mercosur? Would Brazil be willing to fully integrate some industrial sectors of the economies of the region with its internal market providing a new engine of growth, in addition to commodity exports to China? What would the implications be for the countries - Peru and Chile - that have already signed Free Trade Agreements with both the US and China?

\section{Conclusion}

There is no doubt that the rise of China has created new challenges for Brazilian industry, the outcomes of which are as yet still not clear. While Chinese goods are taking an increasing share of the domestic market, they remain a relatively small proportion of total sales of manufactured products overall. Claims that China is a major factor leading to deindustrialization in Brazil therefore seem exaggerated. Similarly, although Brazil has been losing market share to China in the US, EU and Latin American markets, given the size of the domestic market and the relatively small proportion of industrial output that is exported, this too has not had a major impact on aggregate industrial production up to now.

This is not to deny that at the industry level, some sectors have been affected quite seriously by Chinese competition. As shown above, these are not only traditional industries such as footwear, garments and textiles but also industries which are normally regarded as medium or high technology. Indeed, as far as the domestic market is concerned, the penetration in these traditional sectors has been below average, and the highest level of Chinese share in domestic consumption has been in computers and other electrical and electronic products. In export markets both traditional industries and more advanced sectors have lost market share to Chinese products.

Although Chinese competition in the domestic market overall has not had a major negative impact on manufacturing production or employment up to now, it continues to grow so that there is no room for complacency. An increasingly protectionist response is not a solution in the longer term and would be likely to face challenges within the WTO. In addition, protecting the domestic market from Chinese goods does nothing to reduce the challenge posed by Chinese competition in third markets. 
Measures are required to make Brazilian manufacturers more competitive both at home and abroad. One focus of attention here must be the real exchange rate which has appreciated strongly vis-à-vis both the US dollar and the Chinese RMB since 2003. While this partly reflects the high level of commodity prices for goods that Brazil exports, steps need to be taken to moderate the appreciation of the Real if Brazilian manufacturers are to compete.

Brazilian industry also needs to become more competitive through increases in productivity, which has grown slowly in recent years. This requires an active industrial policy focused on promoting technological change and improving skill levels. ${ }^{51}$ It needs to seek more access to other Latin American markets, where it is losing ground relative to China. In order to do that, traditional freetrade mechanisms are not sufficient. Brazil may take the lead in promoting new regional integration schemes, showing that real advantages can come about for its Latin American partners, enabling them to develop some sectors of their manufacturing industry. In other words, the survival of Brazilian industry may provide space for the other Latin American countries to avoid complete deindustrialization and being pushed into a raw materials' corner. However, this will not be achieved by just following the market mechanisms and adapting passively to the rise of China.

The manufacturing sector remains a force within the Brazilian economy. Chinese competition and the new international context, that the rise of China has helped shape, presents new challenges for Brazilian industry but there is no reason why, with appropriate policies and institutions, it cannot meet these challenges and develop a new dynamic pattern of development.

51 See IEDI, Contibuições para uma Agenda de Desenvolvimento do Brasil (Sao Paulo: Instituto de Estudos para o Desenvolvimiento Industrial, 2011), p. 33. For more detailed proposals on industrial policy for Brazil, see IEDI, Indústria e Política Indusrial no Brasil e em Outros Países (Sao Paulo: Instituto de Estudos para o Desenvolvimiento Industrial, 2011), pp. 67-83. 